\title{
Ortaokul Türkçe Ders Kitaplarında Çokluk Kavramı-Anlamsal Çokluk ${ }^{1}$
}

\author{
Serdar YAVUZ \\ Doç. Dr., Fırat Üniversitesi, Eğitim Fakültesi, Türkçe ve Sosyal Bilimler \\ Eğitimi Bölümü, Türkçe Eğitimi Ana Bilim Dalı \\ serdaryavuz@firat.edu.tr \\ Orcid ID: https://orcid.org/0000-0001-9401-4304
}

Ayșe ERDOĞAN

Uzman

ayse_erdogan1624@hotmail.com

Orcid ID: https://orcid.org/0000-0003-2572-8295

\begin{abstract}
$\ddot{O} z$
Dil, beraber yaşayan insanların anlaşmalarına imkân sağlayan, ortak paydada buluşabildikleri seslerden oluşan bir sistemdir. Varlıkları, nesneleri ya da eylemleri ifade etmek için dilde belirli sınıflandırmalar yapılmaktadır. $\mathrm{Bu}$ sinıflandırma içerisinde yer alan ve dünya dillerinde sayı kategorisini oluşturan çokluk kavramıdır. Çokluk, bir nesne veya kavramın çok olması, sayı bakımından birden fazla olmasıdır. Dillerde varlıkların sayısal değeri teklik ve çokluk kavramlarını ortaya çıkarmıştır. Türkçede varlıklar sayısal bir değer olarak teklik veya belirsiz çokluk olmak üzere iki kategoriden oluşmaktadır. Türkçede varlıklara birden fazla olma özelliği kazandıran biçimbirim +lAr çokluk ekidir. Bu ek, çokluk ya da çoğul denildiğinde akla gelen ilk biçimbirimdir ve çokluk kategorisini tek başına karşılamaktadır. Türkçede çokluktan anlaşılan isimlerin çokluk ekini alarak biçimsel açıdan çokluk kavramını karşılamasıdır. Oysa +lAr çokluk ekini almayan bir cümle de çokluk anlamı taşıyabilmektedir. Bu durum, bireyin ana dilini kullanarak kendisini doğru bir şekilde ifade edebilmesinin bir sonucudur. Söz; bireyin düşüncesini aktarmaya imkân tanıyan öznel dilidir, bu nedenle birey çokluk kavramını anlatmak isterken şekilsel özelliklerin dışına çıkıp cümlenin anlam yönünden de yararlanabilmektedir. Çokluğu varlıklara sayısal bir değer kazandıran kategori olarak ele aldığımızda, anlam yönünden en az iki kavramın bir araya gelmesi çokluk için yeterlidir. Sonuç olarak çokluk
\end{abstract}

${ }^{1}$ Makale Geliș/Kabul Tarihi: 04.08.2019 / 22.10.2019

Künye Bilgisi: Yavuz, S., Erdoğan, A . (2019). Ortaokul Türkçe Ders Kitaplarında Çokluk Kavramı-Anlamsal Çokluk. Kahramanmaraş Sütçü Imam Üniversitesi Sosyal Bilimler Dergisi, 16 (2), 363-393. DOI: 10.33437/ksusbd.629470 
kavramı bir sayı kategorisinden oluşmaktadır, yapısal çokluğun dışında anlamsal çokluktan da bahsedilmesi gerekmektedir.

Anahtar Kelimeler: Türkçe, Sayı Kategorisi, Çokluk Anlamı, Anlamsal Çokluk Ortaokul Türkçe Ders Kitabı.

\title{
Plurality Concept in Secondary School Turkish Books - Semantic Plurality
}

\begin{abstract}
Language, which gives a chance to the people living together to get along and find a common ground together, is a system that consists of sounds. Some specific classifications are done in language to express entities, objects and actions. It is the plurality concept that is involved in this classification and that creates the numerals category in world languages. Plurality is objects or concepts that are many, being more than one in terms of numbers. In languages, the entities' numerical value created the singularity and plurality concept. In Turkish, the entities are made up of two categories which can be defined as singularity or indefinite plurality in numerical values. In Turkish, the morpheme that gives the meaning "to be more than one" to the entities is the "-lAr " plurality affix. This affix is the first one that comes to mind when plurality or plural is mentioned and corresponds the plurality category on its own. In Turkish, what is understood from plurality is this: nouns, by taking the plurality affix corresponds with plurality concept formalistically. However, a sentence that does not include the "-lAr" affix can also carry the meaning of plurality. This situation is the consequence of a person who expresses himself in the correct way by using his mother tongue. "The word" is the subjective language that allows an individual's thoughts to transfer and that's why when the individual wants to express the plurality concept, he can also benefit from the sentence's semantic meaning by going out of formal characteristics. When we approach the Plurality as a category that brings the entities a numerical value, in terms of semantics at least two concepts coming together is enough for Plurality. As a result, the plurality concept is made up of a numeral category and besides from structural plurality, semantic plurality is needed to be talked about too.
\end{abstract}

Keywords: Turkish, Numerals Category, Plurality Meaning, Semantic Plurality, Secondary School Turkish Lesson Book. 


\section{GİRIŞ}

Dil, düşüncenin dişa vurumudur. İnsan, dış dünyada gördüğü ve etkileşim içinde bulunduğu varlıkları ya da durumları önce zihninde anlamlandırmaya daha sonra ise açıklamaya çalışmaktadır. İnsan; ana diliyle düşünüp konuşmakta, hayatını bildiği kavramlar üzerinden anlamlandırmaktadır. Bu noktada söz, bireyi anlaşılır kılan ve zihnindekileri açığa çıkarmasına olanak tanıyan bir vasıtadır.

Dil; birbiriyle iç içe ve çok sıkı ilişkiler içerisinde işleyen ses, bürün, biçim, söz dizimi ve anlam özellikleri olmak üzere beş ayrı dizgeden oluşmaktadır (Aksan, 2016, s. 17-18). Her biri dilin farklı bir yanına ortaya koyan bu dizgeler bir bütün halinde dili, etkili ve anlaşılır kılmaktadır. Doğru bir dil edimini için bu dizgelerin her biri dilin grameri oluşturulurken dikkate alınmalıdır. Bu bağlamda dilin dizgelerinden biri olan anlam dizgesi de bu düzenin ayrılmaz bir parçasıdır.

Anlam; bir kavramı oluşturan küçük unsurlardan bağımsız olarak bütününden edindiğimiz çıkarım ya da kavramın ifade alanının zihnimizde bıraktı̆̆ karşılıktır. Anlam, dış dünyada bulunan bir varlığın ya da dildeki bir birimin aktardığı, bizlerde uyandırdığı kavram ve içeriktir (Karaağaç, 2013, s. 115). İnsan zihni karşılaştığı olaylarda veya durumlarda bütüne odaklanıp onu anlamlandırmaya çalışmaktadır. Daha sonra ayrıntılara yönelince bütünü oluşturan unsurları ayrı ayrı kavrayabilmektedir.

Duygu ve düşünceyi dile getiren cümleler, farklı kelimelerin anlamsal bir bütünlük içerisinde kullanımıyla oluşan bir düzendir. Bu düzende her kelime ayrı anlam taşısa da cümle bir bütün olarak algılanıp anlamlandırılmaktadır. Düşünceyi yansıtan cümleler; birbirinden kopuk, bağımsız kelimeler yerine anlamsal açıdan birbirini tamamlayan kelimelerden kurulu bir yapıya sahiptir. Her cümle, kendisini oluşturan kelimelerin anlamsal bütününden oluşmaktadır. Dil; ses, yapı, sözdizimi ve anlam açısından birbiriyle çok sıkı bağlantılarla kurulu öğelerden meydana gelen bir düzen, bir dizgedir (Aksan, 2016, s. 29). Bu düzen içerisinde değerlendirilen dil, çok yönlü bir yapıya sahip olduğundan onu tüm unsurlarıyla ele almak gerekmektedir. Bu nedenle çokluk anlamı, şekilsel bir gramer konusu olmanın dışında cümleyi meydana getiren ses, biçim, söz dizimi ve anlam yönüyle de karşllanabilen dil gibi bütüncül bir yapıya sahiptir. Çalışmamızda çokluk konusu tüm yönleriyle birlikte ele alınmaktadır.

Çokluk, her dilde bulunan varlıkları ilgilendiren bir kavramdır. Sayı kategorisi içerisinde değerlendirilmesi gereken çokluk, Türkçede biçimsel bir sınıflandırmaya tabi tutulmaktadır. Çokluk kategorisi gramer kitaplarımızda genellikle isim çekimi bölümünde yer almaktadır (Kerimoğlu, 2008, s. 144). Türkçede çokluk şekilsel anlayışa bağlı kalınarak -1Ar çokluk ekiyle açıklanan bir konudur. Bu düşünceye bağlı kalındığı vakit -lAr çokluk eki, yalnızca isimlere ve III. çokluk şahıs fillere çokluk anlamı kazandırabilmektedir. Ancak çokluk 
anlamı, en az iki kavramın bir araya gelmesiyle oluşan bir dil birliğidir. Bu anlam bazen şekilsel açıdan karşılanırken çoğu zaman da kelimeler ya da cümleler aracılığıyla karşılanabilen bir sayı kategorisidir. Varlığa, nesneye veya şahsa sayı bakımından birden fazla değer kazandıran tüm unsurlar çokluk olarak nitelendirilmelidir.

Türkçede tekil halde bulunan varlıklar, bir varlığı karşılarken +1 Ar çokluk eki alan varlık, birden fazla olan ancak sayılamayan, belirsiz bir çokluğu karşılamaktadır. Morfolojik olarak +1 Ar ve +1 ArcA ekleriyle yapılan çoklukta, üç anlam kategorisi meydana gelmektedir: belirsiz çokluk, belirli çokluk ve belli belirsiz çokluk (Güner, 2008, s. 18). Türkçede +lAr çokluk ekinin cümleye kazandırdığı anlam, belirsiz bir çokluğu karşılamaktadır. Düşünceye belirli bir çokluk anlamı kazandırılmak istenildiğinde sayı sıfatlarından yararlanılmaktadır. Bir dışındaki sayı sıfatları, Türkçede çokluk ekine bağlı olarak varlık ve eylemlere belirsiz bir çokluk anlamı katan kelimelerden, yine belirsiz sayıda çokluk anlamı taşıyan belgisiz sıfat ve zamirlerden, miktar bildiren zarflardan farklı olarak belirli bir çokluk anlamı taşımaktadır. Meseleye bu açıdan bakıldığında sayı sıfatları, diğer çokluk unsurlarından ayrı değerlendirilebilir.

“Cipte ben, bir köylü, iki bakım memuru, bir de on beşinde bir çocuk var. (7YOEG s.94)" cümlesinde yer alan asıl sayı sıfatları niteledikleri isme belirli bir çokluk anlamı kazandırmaktadır.

"Bütün gün seni aradım." cümlesinde ise biçimsel bir çokluk bulunmamakla birlikte "bütün” kelimesi aramak eyleminin gün içerisinde belirsiz bir zaman aralığında yapıldığını anlatmaktadır. Eylem bir defasında yapılıp tamamlanmamış, belirli sürelerde devam eden bir çoklukta yapılmıştır. "Yarışmayı yine ben kazandım." cümlesinde "yine" kelimesi cümleye belirsiz bir çokluk anlamı kazandırmaktadır. Tekrarlanan eylemde kazanma işinin en az iki defa gerçekleştiği tahmin edilebilir ancak bu sayı daha fazla da olabilir. Tüm bu cümleler çokluk ekinden bağımsız olarak edinilen belirsiz çokluk anlamını örneklendirmektedir.

Çokluk kavramı, bir cümleyi oluşturan unsurlardan ya da cümlenin anlamından anlaşılmaktadır. Bazen sözün diğer kelimelerden farklı seslendirilmesi cümleye çokluk anlamı kazandırabilir. Güner, çokluk kategorisi içerisine dâhil ettiği vurguyla yapılan çokluğa şu cümleleri örnek vermektedir: $\boldsymbol{O}$ kadar kitap okudum ki tahmin edemezsin, Öyle çalıştım ki bilemezsin (2008, s. 19). Çokluk anlamı olmayan bir kelime söze yüklenen vurgu yoluyla da çokluk anlamını karşılayabilmektedir.

Düşüncenin aktarılmasını sağlayan cümleler, bireyin dili kullanma becerisi ölçüsünde farklılaşmaktadır. Benzer dış dünyada yaşasa da her birey, kendi deneyimlerini kendi sözcükleriyle ifade ederek diğerlerinden ayrılmaktadır. 
Ancak, söz söyleme eylemi kişiden kişiye göre farklılaşsa da her birey anlamsal bir bütünlük içerisinde konuşmaya çalışmaktadır. Kavram alanında yer alan ve deneyimleriyle örtüşen durumlarda dilediği sözcügü kullanarak düşüncelerini görünür k1lar.

Anlamı pekiştirmek amacıyla kullanılan ikilemeler, bazı durumlarda çokluk anlamı da taşımaktadır. "Tabak çanak, kap kacak, gece gündüz vb.” gibi kelime birlikteliklerinde hem kullanılan kelimelerin kendi cinsinden kelimeleri hem de kendilerinden sonra ilişkileri olan kelimeyi anlam bakımından çokluk yönüyle etkilemektedir (İlhan, 2009, s. 193). Tek başına çokluk anlamı olmayan bir kelime yinelendiği durumlarda çokluk anlamı kazanabilmektedir.

"Orada şimdiye kadar eşine rastlamadĭ̆g güzellikte bir bahçe duruyordu. (5AHDTP s.22)" cümlesinde biçimsel açıdan ya da kelime düzeyinde çokluk anlamı olan herhangi bir sözcük bulunmamaktadır. Ancak bu cümlede ifade edilen güzellik kavramının normalin çok üstünde bir değer taşıdığını cümlenin bütüne bakarak söyleyebiliriz. Öyleyse yalnızca biçimbirimler veya kelimeler değil cümleler de anlam yönünden çokluğu ifade edebilir. Metnin anlamsal bütününe dikkat etmemek, yalnızca gramer kurallarına bağlı kalarak çokluk ekine şartlanmak bu cümledeki çokluk anlamını göz ardı etmemize neden olur. Söz bireyin düşüncesini aktarmaya imkân tanıyan öznel dilidir, bu nedenle birey çokluk kavramını anlatmak isterken şekilsel özelliklerin dışına çıkıp cümlenin anlam yönünden de yararlanabilmektedir. Çokluğu varlıklara sayısal bir değer kazandıran kategori olarak ele aldığımızda, anlam yönünden en az iki kavramın bir araya gelmesi çokluk için yeterli görülmelidir.

Varlığı sayı yönünden nitelendirmek ona çokluk anlamı kazandırmaktır. $\mathrm{Bu}$ çokluk, bazen sayısı belli olan bir çokluğu, çoğu zaman da belirsiz sayıdaki çokluğu karşılamaktadır. Çalışmamızda çokluk kavramı, anlamsal çokluk başlı̆̆ altında belirli çokluk ve belirsiz çokluk olmak üzere iki alt başlıkta ele alınmaktadır. Araştırma kapsamında 2017-2018 eğitim-öğretim yılında Elazı̆̆ ilindeki ortaokullarda ders materyali olarak kullanılan MEB'e ait 5. sınıf, Başak Yayıncılığa ait 6. sınıf, Ezde Yayıncılığa ait 7. sınıf ve Dörtel Yayıncılığa ait 8. sınıf ders kitapları incelenmiştir. 5, 6, 7 ve 8. sinıf Türkçe ders kitaplarında toplam 128 okuma ve serbest okuma metni araştırma kapsamına alınarak çokluk anlamı incelenmiştir.

\section{Belirli Çokluk}

Türkçede çokluk anlamının farklı şekillerde ifade edilebilmesi çokluğun geniş, kapsamlı bir konu olduğu gerçeğini ortaya çıkarmaktadır. Düşünülenin aksine çokluk eki dışında anlamsal ya da kelime grupları vasıtasıyla da varlıklar çokluk anlamı kazanmaktadır. Varlıkların edindiği bu çokluk anlamı çoğu zaman belirsiz bir çokluğu karşılamaktadır. Ancak yine de dilimizde sayısı kesin olarak 
bilinen, belirli bir çokluk kavramı bulunmaktadır ve bu çokluk, sayı sıfatları aracılığıyla oluşturulmaktadır.

Hayat, dönem gibi sözcükler süresi tam bilinmediği için belirsiz çokluğu karşılamaktadır. $\mathrm{Bu}$ anlamıyla çalışmamızda belirsiz çokluk başlığı altında değerlendirilmektedir. Bu sözcüklerin sayı sıfatlarıyla kullanıldığı durumlarda ise çokluk anlamı belirli bir hale dönüşmektedir. "Dört yıllık ögrencilik hayatımda böyle ödev görmedim. (5-BVM s.40)” cümlesinde kişinin öğrencilik hayatı sayı sıfatı olmadan düşünüldüğünde belirsiz bir zaman dilimini karşılamaktadır. Ancak dört yıllık bir dönem başı ve sonu belli olan bir eğitim dönemini anlatarak belirli bir çokluğu yansıtmaktadır.

“Birlikte nüfus dairesinin yolunu tuttular. (6-AÖVK s.50)” cümlesinde eylemi gerçekleştiren şahısların sayısı metnin bağlamından anlaşılmaktadır. $\mathrm{Bu}$ cümlenin öznesi, Ali ve babasıdır. Ancak nüfus dairesine gidenlerin kim olduğu ve kesin sayısı sadece bu cümleye bakılarak açıklanamaz. Başlangıçta sayısı bilinmeyen özne, metnin bütünü göz önüne alındığında ortaya farklı bir resim çıkmaktadır. Öyleyse birlikte anlamsal bir bütün oluşturan cümleler, bu örüntü bozulmadan beraber değerlendirilmelidir. $\mathrm{Bu}$ duruma örnek olarak tespit ettiğimiz belirli sayıdaki örnekler şunlardır:

Yine beraber oynuyor, mektepten eve birlikte dönüyorduk. (6-At s.35)

Benimle beraber yürüyecek sanıyordum. (7-SO s.77)

"Bu sefer jandarmalar ihtiyarın oğlunun cesedini getirmisler. (8-Msf s.59)" cümlesinde yer alan "bu sefer" söz grubu jandarmaların daha önce de geldiğini belirterek çokluk bildirmektedir. Ancak sayısı bilinmeyen bu çokluk, cümle tek başına değerlendirildiğinde yanıltıcı olmaktadır. Metnin geri kalan bölümlerinde eylemin ikinci kez yapıldığı açıkça anlaşılmakta, dolayısıyla cümlede belirli bir çokluk anlamı bulunmaktadır. Bu durumda doğru bir çıkarım yapmak için cümleyi bağlı bulunduğu paragraf içerisinde değerlendirmek gerekmektedir. $\mathrm{Bu}$ duruma örnek olarak tespit ettiğimiz belirli sayıdaki örnekler şunlardır:

Bir daha muayene edecekler, dedim. (8-DHK s.97) s.103)

"Ne saklayayım geçen gelișimde sevmedim, beğenmedimdi burasını! (8-SA

"Hatta o okurken ktrtasiyeci Mehmet Amca çıkıp esslik etmesin mi? (5-BVM s.40)" cümlesinde üç kişinin varlığı sayıca belirli olan anlamsal bir çokluğu ifade etmektedir. Eylemi yapan şahıs, onu izleyen ve olaya daha sonra dâhil olan şahıs, cümleye üç kişiden oluşan bir grubun var olduğunu göstermektedir. 
"Karı koca yemedik içmedik, sabah akşam nerde kimin tarlasında iş varsa gittik, dişten tırnaktan artırdık, zorla üç beş kuruşsahibi olduk! (8-SA s.103)” cümlesinde eylemi gerçekleştiren şahısların sayısı kesin olarak bilinmektedir. "Karı koca" söz grubu cümleye belirli bir çokluk anlamı kazandırmaktadır.

\section{Belirsiz Çokluk}

Metni oluşturan her kelime farklı anlamlar taşır, ancak bu farklılıklar bir araya geldiği zaman anlamsal bir bütün oluşturmalıdır. Artık birbirinden bağımsız, anlamlı kelimeler yerine bu farklı anlamlarla örülü ortak bir anlam oluşmaktadır. Öyleyse anlam, sözden ayrı tutulmaması gereken, onu tamamlayan bir unsurdur.

Seslerden oluşan her sözcüğün aynı zamanda taşıdığı bir anlam ve bu anlamlara uygun oluşturduğu cümleler vardır. Bazı kelimeler, başka hiçbir kelimeye ya da çokluk ekine ihtiyaç duymadan, başlı başına çokluk anlamı taşımaktadır. Bu kelimelerin kullanımı, bir durumun ya da eylemin bünyesinde çokluk anlamı taşımasını zorunlu kılmaktadır. "Gür" ya da "yoğun" diye tarif ettiğimiz sözcükler, içerisinde çokluk anlamı bulunan olayların anlatıldığı cümlelerde kullanılmak zorundadır. "Tam o strada "Küt!" diye kuru yapraklardan bir yığının üzerine düşmüştü. (5-AHDTP s.22)" cümlesinde geçen "yı̆̆ın" kelimesi birden fazla yaprağın oluşturduğu belirsiz çokluğu ifade etmektedir. Yine "Kitabın Serüveni (5-KS s.172)" cümlesinde yer alan "serüven" sözcügüu kitabın başından geçen ve bilinmeyen sayıdaki olayları anlatarak çokluk bildirmektedir. Bu bağlamda Türkçe ders kitaplarında tespit ettiğimiz anlamsal çokluğu yansıtan sözcükler şunlardır: karışım, akın, gür, yoğun, yı ğın, birikim, birikinti, sel, gelenek, töre, örf, adet, renkli, senfoni, katmerli, serüven, ağır, kocaman, yüksek, aşırı, gökkuşağl, ebemkuşağı, rengârenk, derlemek, işbirliği, seferber etmek, istila etmek, kültür, engin, toplum, toplumsal, toptan, yumak, köklü, evrensel, coşmak, taşmak, aşiret, alışkanlık, unutulmaz, kalabalık.

$\mathrm{Bu}$ bağlamda ortaokul Türkçe ders kitaplarında tespit ettiğimiz ve bağlı bulunduğu cümleye belirsiz bir çokluk anlamı kazandıran kelimelerin yer aldığı cümlelerden bazıları şunlardır:

Tüm bilgisini, birikimini Türkiye için kullanmak üzere savaş veriyor. (5-BDK s.119)

Anadolu'nun geleneksel seyirlik oyunlarl arasinda cirit oyunlarının yeri büyüktür. (5-ACO s.194)

O ibiği kan kırmızı, tüyleri kızıllı karalı, gökkuşăğ gibi çok renkli bir horozdu. (6-Gü s.16) 
Millî Ĕ̆itim Bakanlı̆̆ aracılı̆̆ ile Anadolu halkı ăgzından Türkçe sözlerin derlenmesine başlandl. (8-ATDVÖ s.35)

Çokluk; en az iki kavramın bir araya getirdiği bir dil birliğidir. Çok olmak, sayıca birden fazla olmak çokluk anlamını karşılamaktadır. Çokluk anlamı çoğu zaman çokluk eki aracılığıyla ifade edilse de kelimeler ve taşıdıkları anlamlar da çokluğu anlatabilmektedir. Kelimeler cümlede bazen bir eylemin yapılma sayısını veya eylemi gerçekleştiren şahısların çokluğunu belirtirken bazen de bir defa yapılan ancak çok güçlü, miktar olarak alışılmışın üstünde gerçekleşen bir eylemin çokluğunu belirtebilmektedir.

Gözlerini budaktan esirgemeyen sert bakışl, yağız yüzlü, cesur, vefakâr İnebolu kayıkçısının gür sesi erkekçe gürlüyor: 'kürek başına!' (6-VY s.28) cümlesinde "gürlemek" eylemi sayı bakımından bir defa yapılan bir eylemi karşılarken anlam yönüyle şiddetli, normalin üzerinde duyulan bir sesin çokluğunu anlatmaktadır. Öyleyse eylemin sayı bakımından çokluğu karşılamasının yanı sıra miktarı, yapılma gücü de çokluk bildirmektedir.

Sonsuz, sayısız, bitimsiz, nihayetsiz, ebediyen gibi sözcükler eylemin her zaman devam edeceğini, bir sonunun olmadığını anlatarak çokluk bildirmektedir. Bu duruma örnek olarak şu cümleler verilebilir:

Ustanın bu sonu gelmez nasihatlerinden sikılan kalfa, artık dayanamaz ve gidip bir dükkân açar. (5-PN s.88) s.48)

Öğretmeni Ali'nin bitimsiz soruları karşısında yorgun düşmüştü. (6-AÖVK

Bağırmak, haykırmak, gürlemek, çığlık atmak gibi sözcüklerde eylemin birden fazla yapılmasından çok, güçlü bir biçimde yapıldığı anlaşılmaktadır. Burada söz konusu olan konuşma, normalin çok üstünde yüksek bir sesle yapılarak sesin miktar olarak çokluğu belirtilmektedir. Bu duruma örnek olarak şu cümleler verilebilir: s.35)

O vakit Mıstık, "sen arkama saklan..." diye haykırdı ve önüme geçti. (6-At

Çiftçi daha sözlerini bitirmeden kış mevsimi gürlemiş, "Şimdi beni iyi dinle!" demiş. (7- KM s.101)

Türkçede bir dışında kalan sayı sıfatları, varlıklara belirli bir çokluk anlamı kazandırmakta, bir rakamı çokluk kategorisine dâhil edilememektedir. Ancak bir sayı sıfatı sayılamayan çoklukta varlıkları, nesneleri nitelediğinde çokluk anlamını karşılamaktadır. "Bir elma" söz grubu çokluk bildirmezken, "bir kilo 
elma" ölçülebilen bir çokluk anlamını belirtmektedir. Bu duruma örnek olarak şu cümleler verilebilir:

Biricik ödevim insanlara bir tutam durulmuş renk, bir avuç durulmuş biçim sunmaktır. (7-BBKK s.12)

Şimdi yani üste bir teneke un da mı vermeyeceksin Niyazi? (8-EÇ s.91)

Hep, her zamanki, oldum olası, sürekli, hiç durmadan, durmadan, hiç ara vermeden, devaml, ha bire, hâlâ, hâlen, daima, sıkça, sık sık, düzenli olarak, her eli öpüldügünde, genellikle, genelde... sözcükleri eylemin sürekli yapıldığını ve alışkanlığa dönüştügünü belirterek cümleye çokluk anlamı kazandırmaktadır. "Hep kızımla torunumun evden çıkmalarını gözlüyorum oyuncaklarla oynamak için. (5-O s.10)" cümlesinde "hep" sözcüğü daima yapılan eylemlerin çokluğunu karşılamaktadır. $\mathrm{Bu}$ cümlelerde işin sürekli yapılması çokluk anlamını belirtmektedir. Bu duruma örnek olarak şu cümleler verilebilir:

Uzay İstasyonu'yla yeryüzü arasındaki telsiz bağlantısı sürekli olarak açıktır. (5-UBG s.104)

Üç gün üç gece hiç ara vermeden lapa lapa kar yağmış. (6-DG s.11)

Bu büyükler, oldum olası böyledirler. (6-Gü s.17)

Ha bire tırmık çekiyor, yaprakları öteye öteye kuruyordu. (7-YOEG s.95)

Varlığın ya da eylemin birden fazla yapılması çokluk kavramını yansıtmaktadır. Bu nedenle "Sinan, Padişah'ın önünde bir daha eğilerek: (5ÇDS s.157)" cümlesinde yer alan "bir daha" sözcüğü eylemin bilindiği kadarıyla en az iki defa yapıldığı için çokluk anlamını karşılamaktadır. Ancak söz konusu eylem daha fazla da yapılmış olabilir, burada bahsedilen belirsiz bir çokluktur. Bu çalışmamızda eylemin en az iki defa yapılması çokluk için yeterli ölçüt kabul edilmekte ve bu cümleler çokluk kategorisine dâhil edilmektedir. Bu duruma örnek olarak şu cümleler verilebilir:

Aziz şehitlerimiz, gazilerimiz o gece bir toprak nasıl vatan olur, nasıl vatan kalır bir kere daha bize gösterdiler. (5-15T s.55)

Seni vaktiyle kök boyalartyla, solmaz renklerle dokurlar gene ayak altına serer, gene en zahmetli işlerde kullanirlardı. (7-BBKK s.12)

Hayat, ömür, dönem, süreç, evre, çocukluk, gençlik gibi sözcükler kullanıldığı cümlelerde belirli bir zaman dilimini karşılamakta, bu yönüyle cümleye çokluk anlamı kazandırmaktadır. "Bundan güzel bir ömür mü olur, elli altmış senelik yaşam bundan güzel başlar ve biter mi? (7-SK s.88)” cümlesinde insanın süresi 
belli olmamakla birlikte bir zaman aralığı kapsayan hayatının bütünü kastedilmektedir. Bu yönüyle ömür, yaşam kelimeleri anlamsal olarak belirsiz bir çokluğu ifade etmektedir. Bu duruma örnek olarak şu cümleler de verilebilir:

Çocukluğumsa çok, çok uzaklarda kaldı. (5-O s.11)

Şehzadebaşı benim çıraklık dönemimin yapısı, Süleymaniye'yi kalfalık dönemimde yaptım. (5-ÇDS s.157)

"Mehmet korkunç şekilde annesine benziyordu. (5-KA s.65)" cümlesinde yer alan "korkunç" kelimesi anlam açısından benzerliğin çok güçlü olduğunu belirtmektedir. Korkunç kelimesinin anlamlarından biri de çok aşırı, pek çok, güçlü, şiddetlidir (Türkçe Sözlük, 2009: 1218). Kullanıldığ1 cümleye miktar açısından çokluk anlamı kazandıran bu sözcük, anlamsal çokluğa örnek olmaktadır. Bu şekilde korkunç, korkutucu, şiddetli, dehşetli, dayanılmaz sözcükleri eylemin aşırı, güçlü bir şekilde gerçekleştiğini anlatarak cümleye çokluk anlamı kazandırmaktadır. Bu duruma örnek olarak şu cümleler de verilebilir:

Evliya Çelebi Seyahatnamesinin tam metin çevirisi, korkutucu hacmi ve tabii ki dilinin hem eski hem de çok fazla Evliya'ya özgü oluşuyla, uzmanlara göre bir yapit. (6-YIDBRE s.55)

Bugün dokunanla yirmi beş yıl önce dokunan arasinda korkunç bir düșme var. (7- BBKK s.13)

Arıburnu da dehșetli bir ateș altında... (8-SGBU s.39)

Derece, ölçü kelimeleri, "bu denli, bu kadar" anlamında kullanıldığında cümleye eylemin yapılma oranının fazla olduğu anlamı katmaktadır. "Sanırım gördüğ̈̈ şey her neyse son derece ilgisini çekmis gibi geldi bana. (8-TNV s.23)" cümlesinde biçimsel olarak çokluk belirten herhangi bir unsur bulunmamaktadır. Ancak cümlenin anlamına dikkat edildiğinde görülen şey kişinin ilgisini biraz değil çok, fazla çekmiştir. Cümleye çokluk anlamı kazandıran "son derece" söz öbeği anlamsal açıdan çokluk belirtmektedir. Bu duruma örnek olarak şu cümleler verilebilir:

Annem yaramazlı̆̆ımı ifade etmek için, "O derece yaramazdır ki!" demek için söylemişti bunu. (6-ÜKYGD s.67)

Ancak bu olumlu çabaların, özellikle bazı edebi eserlerin dilinde önemli ölçüde sadeleşme sağlamasına karşıllk, yine de 1930'lu yıllara girerken yazı diliyle halkın konuştuğu dil arasında inanılmaz derecede büyük bir uçurum vardı. (8-ATDVÖ s.35) 
"O çalı çırpının sereserpe gelişstiği, bu denizlere diklemesine inen toprak öyle tasslık, öyle taşlıktı ki... (8-KVDS s.114)" cümlesinde yer alan "öyle” kelimesi anlamsal açıdan toprağın anlatılmayacak kadar çok taşlık olduğunu belirterek çokluk bildirmektedir. "Bu sözler o kadar tesirliydi ki ruhumda âdeta yeni bir meleke, o zamana kadar bilinmeyen mefkûre melekesi yarattr. (8-BV s.69)" cümlesinde ise sözlerin tesirinin az değil çok olduğu "o kadar" söz grubuyla anlatılarak cümleye çokluk anlamı kazandırılmaktadır. Öyle, öylesine o kadar, bu kadar, ne, kelimeleri bağlı bulundukları cümleye düşünülenden çok, pek çok, fazla anlamları kazandırarak çokluk kavramını yansıtmaktadır. Güner, bir dil ögesinin şekilsel görüntüsüyle anlamı arasındaki farklılık vurgu yoluyla sağlanarak cümleye çokluk anlamı kazandırılmaktadır; "O kadar kitap okudum ki tahmin edemezsin." ve "Öyle çalıştım ki bilemezsin.” (2008, s. 19). "O kadar ve öyle" sözcüklerinin cümleye çokluk anlamı kazandırdığını ve bunu "Vurguyla Yapılan Çokluk" olarak sınıflandıran Güner, çokluk kavramını biçimsel gramer anlayışından farklı açıklamıştır. Bu duruma örnek olarak şu cümleler verilebilir:

"Sen ne kadar da yorulmuşsun böyle." dedi. (5-GUY s.35)

Deyince kızın yüreğine öyle bir ateș düşü̈s, öyle bir ateș düşü̈ş ki yanıp kül olmaya az kalmış. (7-TK s.72)

Çok, çokça, pek, pek çok, pek az, azıcık, bol bol, fazla, fazlaca, çok fazla, epey, epeyce, gayet, olağanüstü, fevkalade, harikulade gibi kelimeler; fiil ve fiilimsilere, sıfatlarla başka zarflara aşırılık anlamı katan azlık-çokluk zarflarıdır (Vural ve Böler, 2012, s. 205). Muazzam, mükemmel, muhteşem, müthiş, harika, harikulâde, fevkalade, olağanüstü, inanılmaz kelimeleri zarf görevinde bulunan, cümleye miktar yönünden alışılmışın dışında, aşırı, çok, pek çok anlamları katarak çokluk kavramını karşılamaktadır. Bu kelimelerin yer aldığı ifadelerde söz konusu olan iyi değil iyinin de ötesinde mükemmel ya da harikulâdedir. Burada söz dizimine bağlı olarak varlığa ya da eyleme miktar anlamı veren azlıkçokluk zarfı olmasının yanı sıra kelimenin anlamsal olarak da çokluk kavramını yansıtması bu kelimeleri her iki başlık altında incelememizi sağlamıştır. Bu duruma örnek olarak şu cümleler verilebilir:

Cümleleri yaptıklarını çok basite indirgese de muazzam derinliğe sahip bir insanın dünyasına girmenin keyfini çıkarmanız dileğiyle. (5-BDK s.119)

Bunun yanında, fermuar ve ayakkabı bağcı̆̆ı çoktan icat edilmişti ve her ikisi de mükemmel çalıștyordu. (6-VCC s.47)

Matematik ögrretmeni -o zamanki deyişle riyaziye muallimi- ondan, "Çok zeki çocuk!" diye söz eder; resim ögretmeni, "Harikulade bir kabiliyet!" diye onu över; jimnastik öğretmeni, "Selim fevkalade bir çocuk, lastik gibi vücudu var!" derdi. (8-S s.21) 
Eylemin sona ermeyip uzun süre devam ettiğini anlatan kelimeler, işin yapılma zamanının çokluğunu belirterek cümleye çokluk anlamı kazandırmaktadır. "Böylece cirit bir düzen içinde sürer gider. (5-ACO s.195)"cümlesinde eylem uzun zaman yapılmaya devam eder ve sona ermez. Öyleyse hem süre açısından hem de bu süre zarfında birçok defa yapılan işin çokluğu anlatılmaktadır. Bu duruma örnek olacak başkaca cümleler şunlardır:

Türkler, bu sporu binlerce yıl önce Orta Asya'da başlatmışlar, yüzylllar boyunca bu geleneği sürdürerek Selçuklularla birlikte Anadolu'ya getirmişlerdir. (5-ACO s.194)

Magazin dergilerine dadananlar vardı aramızda, olanca ukalalığımızla "Sen onları mı okuyorsun?" derdik. (6-ÜKYGD s.67)

Bir çiftçi sürekli olarak, klş mevsiminin habersiz geldiğinden șikâyet edip dururmus. (7- KM s.99)

"Doğuştan, yaradılıştan gelen veya ezelden beri devam eden" söz grupları eylemin çok uzun zaman önce var olduğunu ve günümüzde de varlığını sürdürdügünü anlatarak çokluk kavramını karşılamaktadır. Burada söz konusu olan eylem, uzun yıllar boyunca yapıldığı için zaman açısından bir çokluk anlamı bulunmaktadır. Bu duruma örnek olarak şu cümleler verilebilir:

\section{Ben ezelden beridir hür yașadım, hür yașarım, (5-BVM s.41)}

Yalnız matematiğe doğuștan bir yeteneğim, şiir ve edebiyata da tutkulu bir isteğim vardl. (8-BV s.66)

"Birlikte, beraber, bir arada, topluca, el birliğiyle, el ele vererek, birleşmek, karışmak, kaynaşmak" sözcükleri işi gerçekleştiren birden fazla şahıstan bahsederek cümleye sayısal bir değer kazandırmaktadır. "Zeybek türküleri söylüyorlar bir ăğzdan. (8- MOBG s.50)" cümlesinde türkü söyleme işini üstlenen kişilerin çokluğunu "söylemek" fiiline getirilen +1Ar çokluk ekinin dışında "bir ağızdan" tamlama grubu da karşılamaktadır. Birlikte, beraberce yapılan eylemlerde belirsiz ancak sayısal olarak birden fazla olan şahısların çokluğu söz konusudur. Bu duruma örnek oluşturan başkaca cümleler şunlardır:

Tüm güvercinlerin kabul etmesiyle birlikte aynı anda kanat çırparak havalanmışlar. (5-G s.73)

Ancak el ele verirsek dostumuz kurtulur. (7-DA s.67)

"Daha o günden Atatürk, ęgitim birliğinin önemini vurguluyordu. (8-EHÖ s.32)" cümlesinde ise "birlik" sözcüğü cümleye, benzer bir amaç için birbirinden bağımsız görev yapan birden fazla unsurun bir araya getirilerek birleştirilmesi 
anlatılmaktadır. Farklılık gösteren bu unsurların aynı çatı altında toplanması cümleye çokluk anlamı kazandırmaktadır. Bu duruma örnek olarak şu cümle de verilebilir:

"Millet; dil, kültür ve ülkü birliği ile birbirine bağll olan vatandaşların oluşturduğu siyasi ve sosyal toplumdur." (8-ATDVÖ s.34)

“Tıpkı perșembe günü gibi...(6-At s.35)” cümlesinde yer alan "tıpkı” kelimesi cümleye eylemin daha önce de yapıldığı anlamını vermektedir. Bahsedilen olay, en az iki defa gerçekleşerek cümleye belirsiz bir çokluk anlamı kazandırılmıştır. $\mathrm{Bu}$ duruma örnek olarak şu cümleler verilebilir:

Ben daha önce de yașadım bu olayl, biliyorum. (5-KTS s.236)

Söze bașlarken de söylediğim gibi tatlı dil, sevimli görünmeyen hatta soğuk görünen yüzleri bile isitır, cana yakın kılar. (8-TDi s.12)

"Söyleşi, tanışma, tartışma, toplantı, karşılaştırma, karşılık vermek" gibi tek başına yapılması mümkün olmayan, en az iki kişi gerektiren konuşma ve olayları anlatan bu kavramlar, cümleye çokluk anlamı kazandırmaktadır. Bu duruma örnek olarak şu cümleler verilebilir:

Prof. Oktay Sinanoğlu ile 1997 yılında tanıştım, gazetecilik yapıyordum ve bir dergide kendisiyle bilim dünyası hakkında yapılan bir söyleșiyi okumuştum. (5BDK s.118)

\section{“ÖZELLIKLE KÖSTEBEK, RÜZGÂR VE AYLA HANIM İSBBIRLI ĬĞ YAPARSA.” (6- AÖVK S.49)}

Bu metin, haklar ve zorunluluk kavramlarının tartıșlldı̆̆ "Çıtır Çıtır Felsefe" dizisinin on beşinci kitabı olan "Haklar ve Ödevler" kitabından alınmıştır. (6ÖG s.74)

“Bir türlü söndüremezsin. (7- YOEG s.95)” cümlesinde çokluk anlamı taşıyan herhangi biçimsel bir unsur yoktur. Ancak uzun süre uğraş verilen veya beklenilen durumların ardından kullandığımız "bir türlü" söz grubu zihinsel olarak bu cümlede çokluk anlamı olduğunu düşündürmektedir. Uzun süreli ve belirsiz sayıda tekrarlanan eylemlerin anlatımında hem süre hem de bu süre zarfında yapılan farklı çalışmaların varlığı, bu cümleye çokluk anlamı kazandırmaktadır. Bu duruma örnek olarak şu cümleler verilebilir:

Bütün aramalarıma karşın, nereye saklandıklarını bir türlü bulamıyorum. (6$K U$ s.18) 
Bıçağın açtığ yara zamanla kapanır; dil yarası, ruhun en gizli taraflarına doğru boyuna işler, bir türlü kapanmak nedir bilmez. (8-TDi s.10)

"Çeşitli, türlü, değişik, farklı" kelimeleri aynı kavramı ya da varlığı çağrıştıran birbirinden farklı örneklerin olduğunu belirtmek amaciyla kullanıldığında cümleye belirsiz bir çokluk anlamı kazandırmaktadır. "Ağaçlarında da türlü meyve, türlü koruk... (7-TK s.71)" cümlesinde "meyve" ismi çokluk eki almadığı halde tekil bir isim değildir. "Türlü" kelimesi birbirinden farklı ancak belirsiz sayıda meyvenin çokluğunu anlatarak cümleye çokluk anlamı katmaktadır. Bu duruma örnek olarak şu cümleler verilebilir:

Afyon taraflarında iyiden iyiye çeșitlenir çalgı türleri. (6-HGE s.56)

Dört tarafta beyaz badanal tenekeler, sakstlar içinde küpe çiçekleri, ortancalar, karanfiller; tarhlarda ttılar, sardunyalar, katmerler, şebboylar, akşamsefaları, daha türlü çiçekler... (8- SA s.105)

"Yllgınlığa kapılmayan de Mestral ürününü Amerika'ya götürdü ama orada da benzer bir tepkiyle karşılaştı. (6-VCC s.47)" cümlesinde "benzer" sözcügü eylemin daha önce de farklı bir şekilde yaşandığını anlatarak cümleye çokluk anlamı kazandırmaktadır. "Yani bütün bilim adamlarında ortak olan özellikleri araştırmak.(6-NNZNME s.40)" cümlesinde ise ortak olarak adlandırılan durum, çok sayıda şahısta görülen dolayısıyla benzer özellikleri taşıyan kişilerin çokluğunu ifade etmektedir. Her iki durumda da birbirine yakın ya da aynı özellikleri yaşayan şahısların, olayların belirsiz çokluğu anlatılmaktadır. $\mathrm{Bu}$ duruma örnek olarak şu cümleler verilebilir:

Türklerin ata sporu olan cirit oyunları, Asya'da ve Avrupa'da, başka milletleri de etkilemiş, ciride benzer oyunlar türemiştir. (5-ACO s.195)

Acaba bilim adamlarını, diğer insanlardan ayıran bu ortak özellikler neler olabilir? (6- NNZNME s.40)

+cA ekiyle yapılan "onca, bunca" kelimeleri cümleye miktar yönünden belirsiz bir çokluk anlamı kazandırmaktadır. Anlam olarak bakıldığında bu sözcükler, azlık-çokluk zarflarında olduğu gibi cümleye "o kadar, çok, fazla" anlamları katmaktadır. "Bunca sorun dururken dille uğraşmayı gereksiz bulanlar var midır, bilmiyorum. (8-TNV s.22)” cümlesinde sorunun bizim düşündügümüzden daha çok olduğunu anlatan "bunca" sözcüğü cümleye zihinsel açıdan çokluk anlamı kazandırmaktadır. Bu duruma örnek olacak başkaca cümleler şunlardır:

Sevindi onca (6-AG s.22) 
Adamlar onca masraf edip her şeyin en iyisini, en güzelini sunuyorlar, yalnızca siz mutlu olasınız diye bulunmadıkları özveri kalmıyor; tutturmuşsunuz "Ne demek?" diye. (8- TNV s.23)

“Adamlar, var güçleriyle ipe asıllyordu. (5-ÇDS s.159)" cümlesinde "var gücüyle” ifadesi bireyin varlığının bir kısmını değil tümünü ortaya koyduğunu anlatarak güç, kudret sözcüğünü miktar yönünden nitelemektedir. Elindeki gücün tamamının kastedildiği bu durum, çokluk kavramını anlamsal olarak karşılamaktadır. Buna örnek olarak şu cümleler verilebilir:

Magazin dergilerine dadananlar vardı aramızda, olanca ukalalığımızla "Sen onları mı okuyorsun?" derdik. (6-ÜKYGD s.67)

Bilmedik ki disle, tırnakla, kanla, canla tabiat denilen canavarı yenmek lazımdir. (8- KVDS s.116)

"Ben bütün heyecanımla kapıyı dövmeye başladım. (7-YOEG s.96)" cümlesinde bahsedilen kişinin sahip olduğu heyecanın tamamıdır. "Tüm, bütün, yüzde yüz, tamamen” kelimeleri nitelediği ismin büyük bir bölümünü işaret ederek çokluk anlamını karşılamaktadır. "Büsbütün öksüz yapıyor. (8- KÖ s.61)"cümlesinde "büsbütün" kelimesi çok anlamında kullanılarak cümleye çokluk anlamı kazandırmaktadır. Bu duruma örnek olarak şu cümleler de verilebilir:

Bu da Türkiye halkını, yüzde yüz müspet ilme dayalı ilk eğitim terbiyesinden geçirmeye bağlı idi. (8-EHÖ s.32)

Birazdan silahlar tamamen susar... (8-SGBU s.40)

"Bütçe ve cephane" kelimeleri biçimsel olarak tekil halde olan ve bu durumda tekil ismi karşılamaları gereken isimlerdir. Ancak aynı türden silahların genel adı durumundaki "cephane" sözcüğü bir kümeyi işaret ederek cümleye belirsiz bir çokluk anlamı kazandırmaktadır. "Cephane taşıdı arkasından. (7-AKS s.37)" cümlesinde söz konusu tek bir silah olmadığ karşılayan "cephane" sözcügü çokluk bildirmektedir. "Kütüphaneye dikiş makinelerini temin ederken devletin verdiği bütçeyi kullanmaz, makineleri yardımseverlerin katkistyla temin etmeyi planlar. (6-EKMA s.44)" cümlesinde ise bütçeden kastedilen miktarı bilinmeyen ancak birden fazla dikiş makinesi alınabilecek kadar çokluktaki paradır. Bu durumda "bütçe" sözcügü cümleye belirsiz bir çokluk anlamı kazandırmaktadır.

"Paylaşmak, dağıtmak" gibi üleştirme anlamı olan eylemler, miktar olarak çokluğu zorunlu kılan durumları anlatmak için kullanılır. Bir şeyin paylaşılması her şeyden önce onun yeterli miktarda var olmasını gerektirmektedir. Bu yönüyle 
"paylaşmak, dağıtmak" kavramları, çokluk anlamı taşıyan eylemlerdir. "Ahaliye yardım dağıtacakmıș, odur... (8-EÇ s.92)" cümlesinde paylaşacak kadar çok olan yardımlar anlatılarak cümleye çokluk anlamı kazandırılmaktadır. Bu duruma örnek olarak şu cümleler verilebilir:

Daha sonra ögrendiklerimi derste sınıf arkadaşlarımla paylaștım. (7-AA s.29)

Elimdekini avcumdakini göz göre göre sizlere dağıtıyorum işte. (8- EÇ s.90)

"Gözün bile göremeyeceği bir hızla koşmasını öğrensen... (7- KK s.59)" cümlesinde eylemin yapılma süresinin "ölçülemeyen kadar çok hızlı" olduğunu anlatarak cümleye çokluk anlamı kazandırılmaktadır. Burada bahsedilen çokluk, eylemin hızını miktar yönünden belirten bir çokluktur. Bu duruma örnek olarak şu cümleler verilebilir:

\section{Bora gibi kasirga gibi Atatürk'üm(6-AG s.23)}

Yolculardan kılıksız bir ihtiyar Yahudi, güvertede dünyadan habersiz, hırs ve heyecan içinde eşyaların istif etmekle meşgul iken vincin altına girmiş ve tam o sirada demir kancadan kurtulan bir iri denk, olanca ă̆ırlığıyla adamın başına inerken o, essi bulunmaz bir çeviklikle hemen firlamıs, kucaklayınca Yahudi'yi ölümden kurtarmıştı. (8-GBH s.79)

Deyim; ifadeyi güzelleştirerek söze canlılık kazandıran kalıplaşmış söz öbekleridir. Deyimler, anlama uygun kullanıldığı zaman duygu ve düşüncenin doğru ve etkileyici bir biçimde aktarılmasını sağlamakla beraber bazıları anlamsal olarak da çokluğu karşllayabilmektedir. "Sadece sorulanlara cevap ver," demekten dilinde tüy bitmiști. (6- AÖVK s.48)" cümlesinde "dilinde tüy bitmek" deyimi "defalarca anlatmak, çok söylemek" anlamında kullanılarak cümleye çokluk anlamı kazandırmaktadır. Bu duruma örnek olarak şu cümleler de verilebilir:

Atatürk'ün öldü̈̆̈̈, bayrağın onun için yarıya çekildiği kara haberi kulaktan kulağa dolaștı. (6-BAA s.25)

Öfkeden deliye dönen Ali, "İki gece daha kalacă̆ımızı söylemiştik; odamızı başka birine vermeye hakkınız yok!” diye bağırıyor. (6-ÖG s.74) M s.19)

Önce çarşıya indik, çarşı tam bir bayram çarşısıydı yani ana baba günü. (7-

Iç̧imden kendi bildiğim ve dilimden düşürmediğim üstatlarımın seçme şiirlerini fisıldar, bunların yanında Bilal'in sözlerini adeta gülünç bulurdum. (8Ac s.70) 
Tekrar yoluyla anlamı güçlendiren ikilemeler, cümleye çokluk anlamı kazandırabilmektedir. İkilemelerin cümleye kazandırdığı bu çokluk, bazen sık sık ya da ara sıra yapılan bir eylemin süresini anlatılırken bazen de yapılan eylemin süresinden ziyade miktarı çokluk açısından vurgulanmaktadır. "Karı koca yemedik içmedik, sabah akșam nerde kimin tarlasında iş varsa gittik, dişten tırnaktan artırdik, zorla üç beş kuruş sahibi olduk! (8- SA s.103)" cümlesinde "sabah akşam" söz grubu eylemin sıkça tekrarlandığını belirterek çokluğu ifade etmektedir. "Beni günlerce üzen, yoran bir hülya avcıllğının hasadı olan sedeflerimi kenarları yaldızl defterlerde olduğu kadar zihnimde de itina ile saklar, vakit vakit onlarl kendi kendime mirldanmaktan büyük bir haz duyardım. (8-Ac s.70)" cümlesinde eylem yine çokluğu bildirir; ancak bu sürekli olan bir çokluk değil, arada sırada yapılan bir çokluktur. "Gürül gürül akan sulara bakıp: (7-TK s.72)" cümlesinde şiddetli akan suyun miktarı belirtilerek çokluk kavramı karşılanmaktadır. Bu duruma örnek olarak şu cümleler de verilebilir:

Pet şişeye girmemiş, klor karışmamıştır doya doya içiniz, yeni ve temiz hava ile su kilcal damarlarınıza kadar yayılsın. (5-R s.229)

Bir yanında sular akıyor oluk oluk... (7-TK s.71)

Eşiklerinde soluk yüzlü, çılak ayakll, ürkek ve sessiz çocukların, ellerinde ekmek kabuğuyla ve çerden çöpden yapılmış oyuncaklarla, ă̆ır ağır, düşünerek ve gülmeden oynadıkları bu evlerin arasında kendi evimi ararım ve âdeta güç bulurum çünkü bunların hepsi benim evim gibidirler. (8-DHK s.97)

Belirli bir zaman aralığında sürekli olarak yapılan eylemleri anlatan "yavaş yavaş, ağır ağır, günden güne" gibi ikilemeler cümleye çokluk anlamı katmaktadır. $\mathrm{Bu}$ ikilemelerde birçok defa yapılması gereken durumlar anlatılmaktadır. Bu durum cümleye çokluk anlamı kazandırmaktadır. Buna örnek olarak şu cümleler de verilebilir:

Gökyüzünde bulut olarak uça uça buraya kadar gelmiştik. (5-KTS s.236)

İnsan yapa yapa öğrenir bir işi. (6-AŞG s.77)

Yayla havasi gibi yayla adamınin toplaya toplaya, biriktire biriktire, sindire sindire aldığ bir hız vardır ki yayla firtınası gibi birden boşanır. (8-Y s.110)

"Yoklayıcıları ile konuștukça Tevfik Efendi açıllyor, inlemesi kesiliyor, artık gözlerini süzmesi, burnundan soluması kalmıyor. (5-H s.216)” cümlesinde zarf fiil görevinde bulunan "konuştukça" kelimesi tekrar tekrar yapilan eylemi niteleyerek cümleye çokluk anlamı katmaktadır. Bu duruma örnek olarak şu cümleler de verilebilir: 
Böyleyken ben, kitaplardaki o resimlere baktıkça yaz tatilinin hayallerine kapılmaktan kendimi alamazdım. (5-OK s.165)

Yengeç sılktıkça sılkmıș. (7-BK s.81)

Ondan sonra aramızda gün geçtikçe derinleșen bir dostluk başladı. (8-S s.21)

Cümleye çokluk anlamı kazandırmanın birden fazla yolu bulunmaktadır. Kişinin zihninden geçenleri anlatması, bunu yaparken seçtiği kavramlar çokluk kategorisinin çeşitlenmesini sağlamaktadır. "Kovalar dolusu sivı karışım ve kürekler dolusu da ilaç, hap gibi şeyler yutmuştu. (6- SKH s.82)” cümlesinde "sıvı karışım ve ilaç" sözcükleri abartılarak anlatılma yoluna gidilmekte, bu durum da cümleye aşırılık anlamı kazandırmaktadır. Abartmada bir durum olduğundan çok fazla büyültülmekte ya da küçültülmektedir. Miktar yönünden yapılan bu aşırılaştırmayla cümleye çokluk anlamı kazandırılmaktadır. $\mathrm{Bu}$ duruma örnek olarak şu cümle de verilebilir:

Henüz lambaların bile yanmadiğl şu erken saatte bir bodrum kapanıklığl duyulan sokaklara karanlık başka türlü, yüreğe kaygl dolar gibi çöküyor, ăğzlarına kadar tasskın bostan kuyularından yöreye kemirici bir yaşlık yayılarak vücuttan önce ruha işliyordu. (8- GBH s.80)

Uzun kelimesi; başlangıcı ile sonu arasında fazla zaman aralığı olan, çok süren anlamına da gelmektedir (Türkçe Sözlük, 2009: 2051). Bu anlamıyla cümlede kullanıldığında zamanın çokluğunu bildirerek çokluk kategorisini yansıtmaktadır. "Ben taşrada fakat yatılı bir okulda, birkaç yıl bulunmuştum; sonra daha uzun zaman İstanbul'da, ögrenci saylsı bine yaklaşan büyük bir klz okulunda ögretmenlik ettim. (8- S s.17)" cümlesinde "uzun" sözcügü bir okulda çalışılmakla geçen zamanın çokluğunu anlatmaktadır. "Seyahatname'si dünyanın belki en uzun gezi anlatısı olduğu gibi, (...) tam anlamıyla bir "ülkeler ve insanlar", hatta "uygarliklar" ansiklopedisi. (6-YIDBRE s.54)"cümlesinde ise aynı sözcük cümleye bir varlığın boyut ya da nicelik bakımından taşıdığı çokluk anlamını örneklendirmektedir. Bu duruma örnek olarak şu cümleler de verilebilir:

Uzun uzadı kasıklarıma, korku damarlarıma bastı. (6-At s.36)

Samimi oluşumun cezasını çekiyorum." diye sızlanan bir dostumu uzun uzun dinlediğim için bu konuşmayı yapıyorum. (7-SO s.77)

“Büyük" sözcügü varlıklara sayısal bir değer kazandırmaktadır. Büyük olarak izah ettiğimiz kavram, normalin üstünde bir niceliğe sahip olmalıdır. Varlığa nicel bir anlam kazandıran bu kelime, miktar bildirdiği için çokluk kategorisini yansitmaktadır. "Devletten büyük destek gören bu dernek, daha sonra Türk Dil Kurumu adını aldı. (8-ATDVÖ s.35)" cümlesinde "büyük" kelimesi yapılan 
yardımın çok fazla olduğunu belirterek cümleye miktar yönünden çokluk anlamı kazandırmaktadır. Bazen de aynı kelime, karşılaştırma yoluyla bir varlı̆̆ın diğerlerinden üstün bir nitelik taşıdığını belirterek ona nicel bir anlam katmaktadır. "Eski Yunan'ın büyük filozofu Sokrates (Sokrat), hiç yazmadı. (7-Ok s.53)” cümlesinde Sokrates’in büyüklügü diğer filozoflara kıyasla taşıdığ 1 değerin çokluğuna bağlıdır.

"Babasına karşı derin bir minnet besliyordu: (8-S s.21)" cümlesinde "derin" kelimesi az olmayan, çok, fazla anlamında düşünüldüğünde cümleye ç̧okluk anlamı kazandırmaktadır. Yüzeysel olmayan, detaylı, kapsamlı düşünmek, bir konuyu tüm unsurlarıyla birlikte ele almak hem zaman açısından hem de konunun boyutlarının çok yönlü olması açısından çokluk bildirmektedir. "Bu sükût içinde, oynadıkları oyunun teferruatına dalarak düşündükleri hissediliyor. (8- DHK s.99)" cümlesinde oyunun ayrıntılı olması ve bu ayrıntılar üzerinde derin düşüncelere dalmak çokluğu ifade etmektedir. Bu duruma örnek olarak şu cümle de verilebilir:

Televizyon, tüm kötü güçlerin 60-70 yllda, daha genis düșünürsek 600-700 yılda yapamadĭgını 10 yılda yaptı. (8-TNV s.22)

"Bağlama Türk müziğinde yaygın olarak kullanılan telli bir enstrümandır. (5-TCBEA s.146)" cümlesinde bağlamanın geniş bir coğrafyada, fazlaca kullanılan bir enstrüman olmas1 "yaygın" kelimesiyle anlatılmakta ve bu durum cümleye çokluk anlamı kazandırmaktadır. Biçimsel olarak herhangi bir çokluk eki olmamasına rağmen yaygın kelimesinin çokluk içeren anlamı, bağlamanın çokça kullanılan bir müzik aleti olduğunu dolayısıyla miktar yönünden çokluğunu nitelemektedir. Bu duruma örnek olarak şu cümle de verilebilir:

Radyonun yaygınlaşmaya bașladiğı bu yüzyılın ilk yarısında da ana babalar benzeri kaygıları yaşamışlardı. (8-KAIVVKİ s.15)

“Mimar Sinan, 1489-1588 yılları arasında yaşamış, ünü tüm dünyaya yayılmıs büyük bir mimardır. (7-MS s.9)” cümlesinde Mimar Sinan'ın tüm dünya tarafından tanınması, onu tanıyıp bilen insanların ve ülkelerin çokluğu cümleye sayısal bir çokluk anlamı kazandırmaktadır. Bu duruma örnek olarak şu cümle de verilebilir:

İhtiyar, yünlerin boyanması için dăg köylerinde nam salmıș Duru Kadına göndermek istedi. (6-BBKK s.57)

"Geniş, uçsuz bucaksız" olarak nitelendirilen varlıklar, anlam açısından belirsiz bir çokluk bildirmektedir. Bir varlığın ucu bucağının olmaması onun zihinsel olarak fazlasıyla büyük olduğunu düşündürmektedir. "Şimdi iki yanımız ucssuz bucaksız pamuk tarlaları. (8- MOBG s.49)" cümlesinde nicelik anlamı 
taşıyan "uçsuz bucaksız" söz grubu pamuk tarlalarının büyüklügünü niteleyerek ona çokluk anlamı kazandırmaktadır. Bu duruma örnek olarak şu cümleler de verilebilir:

Ucu bucă̆ı belirsizdi uzunluğumuzun. (5-KTS s.235)

Araştırmalarım sırasında Türkçenin dünyada konuşulan en eski ve köklü diller arasında yer aldiğını, çok geniș bir coğrafyada konușulduğunu, ortak geçmişi paylaşan kardeş ülke ve topluluklar arasında koparllamayacak güçlü bir bağ oluşturduğunu ögrendim. (7-AA s.27)

"Dört yaprakl yoncanın her yaprağındaki besinlerden yeterli ve dengeli bir şekilde yemeliyiz. (5-SY s.202)"cümlesinde "yeterli" kelimesi bir şeyin az olmamakla birlikte miktarı tam bilinmeyen bir oranda olması cümleye belirsiz bir çokluk anlamı kazandırmaktadır. Besinlerden az olmayacak ve kişiye yeterli gelecek bir miktarda alınması sayısal olarak çokluğu anlatmaktadır. Bu duruma örnek olarak şu cümle de verilebilir:

$B u$ nedenle zamanında yatağımıza girmeli ve yeterince uyumalıyız. (5-SY s.201)

Ziyade kelimesi; Arapça çok, daha çok, daha fazla anlamına gelmektedir (Türkçe Sözlük, 2009, s. 2239). Varlığın miktar yönünden çok olduğunu niteleyen bu sözcük, cümleye çokluk anlamı kazandırmaktadır. Bu duruma örnek olarak şu cümleler verilebilir:

Onlara göre bazı öğrencilerin başarılı, diğerlerinin başarısız olmalarında bunlar, zekâdan ziyade etki yapmaktadır. (8-OVMS s.75)

Bu doktor, genç olmadığı hâlde, birçok siyasi sebeplerden dolayı henüz stajını bitirmemisti fakat bana hepsinden yakın bir insandl ve dizimden ziyade sinirlerim üstündeki iyi tesirlerine muhtaçtım. (8-DHK s.98)

"Fakat orası göz gözü görmeyecek kadar karanlıktı. (5-AHDTP s.21)" cümlesinde karanlık kavramının miktarı tasvir edilirken ona sayısal bir değer verilerek cümleye çokluk anlamı kazandırılmaktadır. "Göz gözü görmeyecek kadar" kısacası "çok karanlık" olarak anlatılan bu ifadede varlık, çokluk bildiren bir isme dönüşmektedir. "Tırmanmaktan yorulana kadar uğraştı. (5-AHDTP s.23)" cümlesinde tırmanmaktan yorulana kadar sürekli ve miktar olarak düşünüldügünde ise çokça yapılan eylem, cümleye çokluk anlamı kazandırmaktadır. Bu duruma örnek olarak şu cümleler de verilebilir:

Kutuplardan Ekvator'a kadar gezmedik yer bırakmazdım. (7-KK s.56) 
Çünkü senin cesaretin, vatanseverliğin ve inancın ölçülemeyecek kadar yüksektir. (8- SGBU s.39)

"Her gün eline kâğı̆t kalem alarak annesinin peşinde dolaşıyor, Ayla Hanım'ı soru bombardimanina tutuyordu. (6-AÖVK s.48)" cümlesinde yer alan "soru bombardımanı" tabiri anlamsal olarak hem çokluk hem de eylemin sürekliliğini vurgulayarak zamanının çokluğunu belirtmektedir. Kısacası bu cümlede birden fazla soru sorarak soruların çokluğu anlatılırken bir süre zarfinda durmadan, çok hızlı bir şekilde gerçekleşen eyleme hız açısından da çokluk anlamı kazandırılmaktadır. "Babam, başkomutan edasıyla dut ăgacının az ilerisinde durur ve komutlarını yăgdırmaya başlardı. (8-DDD s.122)" cümlesinde de aynı şekilde çok fazla emir, çok hızlı bir şekilde verilerek hem miktar hem de eylemin hızı anlamsal açıdan çokluk bildirmektedir.

"íkide bir yakasını çekiştiriyor, bir türlü alışamadiğı boyun bă̆ını gevşetmeye çalışıyordu. (7-M s.20)" cümlesinde yaka çekiştirme işinin s1k s1k tekrarlanması cümleye anlamsal olarak belirsiz bir çokluk anlamı kazandırmaktadır. Sıklıkla yapılan eylemleri anlatan "iki de bir" ve ara sıra yapılan eylemleri anlatan "arada bir" kelimeleri işin tekrar sayısını bildirerek cümlenin anlamını çokluk yönünden nitelemektedir. Bu duruma örnek olarak şu cümleler de verilebilir: s.67)

Bir hafta alaturka, bir hafta klasik batı müziği dinlemeye giderdik. (6-ÜKYGD

Arada bir bazı da üst üste top patlar gibi bir şeyler patlyyor. (7-YOEG s.95)

Belirsiz sayıda kişilerin anlatıldığı "el, el âlem, cümle âlem ile kadın, erkek, genç, çocuk" gibi tür isimleri şahısların çokluğunu karşılamaktadır. "Cümle âlem birikmiş işte davullu zurnalı. (5-C s.208)" cümlesinde "cümle âlem” söz grubu içerdiği anlam yönünden büyük bir insan topluluğundan söz etmektedir. Sayıs1 bilinmeyen ancak bir kişiden daha çok olduğu kesin olan bu sözcük, cümleye çokluk anlamı kazandırmaktadır. Bu duruma örnek olarak şu cümleler de verilebilir:

Gerçek manasında terbiyeli ve nazik bir adam veya bir hanım, tanıdiğına tanımadığına, sevdiğine sevmediğine iyi muamele etmeye, hatır saymaya, gönül almaya mecburdur. (8-Msf s.58)

\section{Cümle hasretleri kavuştursun Rabb'im, bizi de... (8-EÇ s.87)}

İş, oluş, hareket bildiren eylemin gerçekleşmesi çokluk anlamı taşımazken eylemin "çılgınca, çıldırasıya, delice" yapılmasını beklemek cümleye aşırılık anlamı katmaktadır. Söz konusu eylemin aşırı bir biçimde yapılmasını istemek 
cümleye miktar yönünden çokluk anlamı kazandırmaktadır. "Tribünlerde geçit resmini selamlayan Atatürk'ü kadın erkek çıldırasıya alkışlıyordu. (8-AK s.28)" cümlesinde alkışlamak eyleminin, normalden daha güçlü bir şekilde yapılması çokluğu belirtmektedir. Bu duruma örnek olarak şu cümleler de verilebilir:

İşte o zaman Küçük Ağa tam deliye döndü ve Emine'yi yanına almak için çllgın bir hirsa kapildı. (5-KA s.66)

Feridun şimdi bunu düşünerek vücudunda mahallenin karanliğl ve gözlerinde Kadıköy'ün ışılkları öyle ölüvermek isteğiyle yanıyordu. (8-GBH s.80)

"Hiçbir devlet kurucusu, Atatürk kadar "eğitim" konusunun hayati önemi üzerinde durmamıştır. (8-EHÖ s.32)" cümlesinde eğitimin ne kadar önemli olduğu anlatılırken onun yaşamak kadar öneme sahip olduğu belirtilmektedir. Atatürk'e göre eğitim çok önemli bir konudur. "Hayati önem" söz grubu varllğa anlamsal açıdan çokluk kazandırmaktadır.

“Kardes kavgasina bir nihayet olsun. (6- Mi s.76)” cümlesinde şekil açısından herhangi bir çokluk eki bulunmamaktadır. Ancak "nihayet" sözcügü cümleye çok uzun süren bir durumun yaşandığını düşündürmektedir. "Altı yaşındayken bir gün, balta girmemis ormanlar üstüne yazılmış "Yaşanmış Öyküler" adlı bir kitapta müthiş bir resim görmüştüm. (6- KP s.62)"cümlesinde "balta girmemiş ormanlar" tabiri günlük hayatta karşılaştığımız bir söz grubudur. Topluluk adı olan "orman" sözcüğü çokluk bildirmektedir. "Balta girmemiş ormanlar" ise insan elinin ulaşamadığı, içerisinde sık ve gür ağaçların bulunduğu bir yeri düşündürmektedir. Çok fazla olan bu ağaçlar, çokluk anlamı taşımaktadır. "Bu seyahat, artık yolculuktan usandığım bir zamana rastlamış olmakla beraber beni atl karıncaya binmiş bir bayram çocuğu gibi eğleniyordu. (8-OY s.47)" cümlesinde ise kişinin geçmişte çok fazla yolculuk yaptığını bize düşündüren "artık" sözcüğü cümleye çokluk anlamı kazandırmaktadır. Tüm bu örnekler, okuyanın zihninde bir durumun miktarına ya da süresine ilişkin bir çokluk anlamının olduğunu düşündürmektedir. Bu duruma örnek olarak şu cümleler de verilebilir:

Benim yașim neredeyse dünyayla eșit. (6-DG s.10)

Bizim sınıf kitaplı̆̆ımızda da pek kitap yoktu; kütüphanede doydum. (6ÜKYGD s.67)

İyi de laf mı? Bunun üstüne çimen mi olur? (7-SK s.91)

Ortada hiçbir sebep olmasa bile dayatmanın yollarını ararsınız; eninde sonunda yapmaya mecbur olsanız dahi iyi yapmaz, baştan savarsınız. (8-TDi s.11) 
Gerçekten dilin, tatlı dil olmak şartıyla, açamayacağı kapı, çözemeyeceği düğüm yoktur. (8- TDi s.12)

Çünkü bu, ha deyince olacak işlerden değildir. (8-TDi s.12)

Nihayet başlarından biri: (8-AK s.29)

Cumhuriyetin kuruluş devrinde bir astrdan beri devam eden medeniyet mücadelesinin kesin zaferi, Medeni Kanun ve Laiklikle kazanılmıştı. (8-EHÖ s.31)

Gözü ve gönlü doyuran türlü yeşillik aralarında bembeyaz kuleleri, kar gibi bağ damarları benek benek ăgarıyor. (8-MOBG s.49)

Temiz maldır, alıcısını bulursa iyi para eder, hele girin dükkâna bir daha görelim, bir klymet biçelim! (8-GBH s.83)

Gel zaman git zaman, günün birinde Mehrali Bey’in kara haberi gelmez mi. (8-EÇ s.84)

Tarihten, bu yayla üstünde, dinmez bir uğultu, bir de Türk göğsü kaldı. (8-Y s.110)

Bir çekişte sökülecek sanılır: Kökü aylklanmakla bitmez. (8-Y s.111) s.119)

Hiç unutamadı̆̆ım bir anı da babamla bülbüllere dair olanıdır. (8-DDD

Kelimeler cümlede bazen bir eylemin yapılma sayısını veya eylemi gerçekleştiren şahısların çokluğunu belirtirken bazen de bir defa yapılan ancak çok güçlü, miktar olarak alışılmışın üstünde gerçekleşen bir eylemin çokluğunu belirtebilmektedir. Bu bağlamda cümleye anlam bakımından belirsiz bir çokluk anlamı kazandıran kelimelere ilişkin elde edilen sonuçları şu şekilde sinıflandırmak mümkündür:

Gelenek, töre, örf, kültür, birikim, yığın, köklü, gökkuşağı, bütçe, cephane gibi kelimeler anlamsal olarak farklı unsurların bir arada olması ya da uzun yıllar süren bir durumun çokluğunu bildirmektedir.

Sayısız, sonsuz, nihayetsiz, bitimsiz gibi kelimeler sonu olmayan, belirsiz ancak birçok kez yapılan eylemin çokluğunu bildirmektedir.

Gürlemek, haykırmak, çığlık atmak gibi kelimeler duyulan sesin normalin çok üstünde bir şiddette olduğunu anlatırken sesin çokluğunu da belirtmektedir. 
Burada söz konusu olan konuşma düzeyindeki ses değil, haykırmak veya çığlık atmak yoluyla daha güçlü bir sesin şiddetidir.

"Bir kova su, bir tencere un" gibi sayılamayan çokluktaki unsurları belirten bir sayı sıfatı, cümleye çokluk anlamı kazandırmaktadır.

Sürekli, daima, devamlı yapılan ve alışkanlığa dönüşen durumlarda eylemin yapılma sıklığı çokluk bildirmektedir. Yine ikide bir, arada bir söz öbekleri de birden fazla yapılan ve tekrarlanan eylemlerin belirsiz çokluğunu bildirmektedir.

Hayat, dönem, süreç, devir gibi kelimeler bir zaman dilimini anlatarak cümleye süre açısından çokluk anlamı kazandırmaktadır.

Birlikte, beraber, el birliği, iş birliği, topluca gibi kelimelerde eylemi gerçekleştiren şahısların sayıca çokluğu anlatılmaktadır. Yine söyleşi, tartışma gibi eylemler de birden fazla şahsı gerekli kılan hallerdir. Bu durumda öznenin sayıca çok olması cümleye şahıs yönünden çokluk anlamı katmaktadır.

El, elâlem, cümle âlem, kadın, erkek, genç çocuk gibi tür isimler bağlı bulunduğu insan topluluğunu karşılayarak şahısların çokluğunu bildirmektedir.

Müthiş, fevkalade, inanılmaz, korkunç, dehşet gibi kelimeler sayılamayacak kadar çok olan, güçlü durumları anlatarak çokluk bildirmektedir. Yine son derece, önemli ölçüde, o kadar, öyle, öylesine kelimeleri cümleye çok, aşırı miktarda yapılan ancak sayılamayan bir durumun çokluğunu bildirmektedir.

$\mathrm{Bu}$ defa, bu kez, gene, yine, tıpkı daha önce olduğu gibi, genellikle gibi kelimelerde eylemin en az iki defa yapıldığı kesin olmakla beraber yine de sayısı tam bilinmeyen bir durumun çokluğu ifade edilmektedir.

Onca, bunca sözcükleri bağlı bulunduğu cümleye zihinsel olarak çokluk anlamı kazandırmaktadır. "Onca sorun" diye ifade edilen bir durum, düşünülenin aksine daha çok sorunu anlatarak çokluk bildirmektedir.

Paylaşmak, dağıtmak gibi üleştirme anlamı olan fiiller, anlamsal olarak belirli bir miktarda varlığı gerekli kılan durumları karşılamaktadır. Bu durumda dağıtılacak kadar nesnenin çokluğunu ifade ederek çokluk bildirmektedir.

Bitmeyen, devam eden eylemler için kullandığımız "devam eder, sürüp gider, şikâyet edip durmak, boyuna tekrarlamak" gibi kelime grupları belirsiz bir süre içerisinde ancak birden çok tekrarlanan eylemin çokluğunu anlatmaktadır.

Ezelden beri, doğuştan ya da yaratılıştan gelen iş ve eylemler zaman yönünden cümleye çokluk anlamı kazandırmaktadır. Burada söz konusu olan bir gün değil, uzun bir zaman dilimidir. 
Değişik, farklı, türlü, çeşitli, ortak, benzer gibi kelimeler anlamsal olarak farklı unsurların karşılaştırıldığı durumları anlatarak çokluk bildirmektedir. Benzerlik ya da ortaklık en az iki varlık ya da şahıs arasında yapılan kıyaslamaya dayanarak çokluk bildirmektedir.

Arka planda belirli bir süreci ve eylemi gerekli kılan "bir türlü” söz öbeği zihinsel olarak uğraşılan, belirli bir çabanın sonucunda söylenen durumları karşılamaktadır. Cümlenin bağlamı dikkate alındığında birçok defa yapılan ancak istenilen sonuca ulaşılmayan durumlarda eylemin sayıca çokluğu zihinsel olarak anlaşılmaktadır.

Bütün, tüm, tamamen, var gücüyle gibi kelimeler var olan bir durumun belirli bir kısmı yerine hepsini anlatarak miktar yönünden çokluk bildirmektedir.

Uzun, derin, geniş, kapsamlı gibi kelimeler eylemi süre ya da boyut yönünden niteleyerek çokluk bildirebilmektedir. "Geniş bir coğrafya” ya da "uzun süren bir eylem" belirsiz bir çokluğu anlatmaktadır. Yine yaygın, tüm dünyaya yayılan gibi ifadelerde geniş bir bölgede birden fazla insan tarafindan bilinen bir durum çokluk bildirmektedir.

Deyimler ve ikilemeler anlamsal açıdan cümleye çokluk anlamı kazandırmaktadır. Kese kese altın ikilemesinde çokluk anlamı belirgindir; ancak ağır ağır, yavaş yavaş kelime gruplarında bir defada gerçekleşmeyen, bir süre ya da birkaç deneme sonucunda oluşacak eylemler anlam dikkate alındığında çokluk bildirmektedir.

Kovalar dolusu ya da ağızlarına kadar dolu, taşkın tencereler söz gruplarında çokluk anlamı vardır. Cümleye miktar yönünden çokluk anlamı abartma yoluyla sağlanmıştır.

Gözün bile göremeyeceği bir hız ya da kasırga gibi, bora gibi kelime gruplarında bahsedilen hı, çokluk bildirmektedir. Miktar yönünden sayılamayan, ancak çok hızlı olduğu cümlenin bağlamından anlaşılan bu durumda hız, çokluğu anlatan bir anlam kazanmıştır.

Büyük sözcüğü bazı durumlarda karşılaştırma yoluyla çokluk bildirir. "Büyük yazar, düşünür" diye nitelediğimiz bir durumda insana verilen ancak ölçülemeyen değer, başkalarıyla kıyaslanarak anlatılmaktadır.

$\mathrm{Bu}$ bağlamda Türkçe ders kitaplarında belirlediğimiz çokluk anlamı belirli olan kelimelerin sinıflara göre dağılımı ise şu şekildedir: 5. sinıflarda 6,6 . siniflarda 4, 7. siniflarda 1, 8. sinıflarda ise 12 olmak üzere toplamda 23 kelime tespit edilmiştir. Türkçe ders kitaplarında belirlediğimiz çokluk anlamı belirsiz olan kelimelerin sınıflara göre dağılımı ise şu şekildedir: 5. sinıflarda 259, 6 . 
siniflarda 311,7 . siniflarda 465,8 . siniflarda ise 524 olmak üzere toplamda 1559 kelime ve cümle tespit edilmiştir. Bu durum yıllara göre sinfflar içerisinde kademeli ve planlı bir geçiş olduğunun göstergesidir.

\section{Sonuç ve Öneriler}

1. Türkçede çokluk şekilsel anlayışa bağlı kalınarak +1 Ar çokluk ekiyle açıklanan bir konudur. Ancak çokluk anlamı, en az iki kavramın bir araya gelmesiyle oluşan bir dil birliğidir. Bir dili; kendisini meydana getiren biçim, kelime, cümle ve anlam dizgelerinden ayrı tutarak değerlendirmek dilin bir yanını her zaman eksik bırakacaktır. Bu nedenle biçimle beraber ona değer kazandıran anlamın da dikkate alınması gerekmektedir. Bu bağlamda Türkçede çokluk anlamı belirlenirken biçimsel olarak kategorinin tek eki olan +lAr çokluk eki ile birlikte kelimeler, kelime grupları ve cümlenin anlamı da dikkate alınarak yeni bir çokluk tasnifi yapılmalıdır.

2. Biçimsel açıdan yaklaşıldığında +1 Ar çokluk ekinin olması çokluk için yeter şart olarak görülmektedir. Ancak cümlede ifade edilen durum çokluk ekinden bağımsız olarak varlığa çokluk anlamı kazandırabilmektedir. Bu nedenle sese dönüşmeyen ancak anlamsal olarak çokluk olduğu düşünülen ifadeler de "zihinsel çokluk" kavramı içerisinde değerlendirilmelidir.

3. Deyimler aşırılık bildiren anlamlarıyla cümlede çokluğu karşılayan söz öbekleridir. Bu nedenle deyimin anlamı dikkate alınarak cümleye çokluk anlamı kazandıran bu kalıplaşmış sözler, çokluk kategorisi içerisinde değerlendirilmelidir.

4. Bir sayı sıfatının, çokluk anlamı taşımadığı fikrine karşı sayılamayan varlık ve nesnelerde belirsiz bir çokluğu karşıladığı göz ardı edilmemelidir.

5. Bir defa yapılan eylemler çokluk anlamı taşımazlar. Ancak burada eylemin yapılma oranı açısından bir çokluk anlamının olmadığı söylenebilir. Aynı durumda bir defa yapılan eylemin yapılma şiddeti, miktarı çok fazla olabilir. Öyleyse bir eylemin çok güçlü bir şekilde yapılması miktar yönünden çokluk olarak değerlendirilmelidir.

6. Cümleye aşırılık anlamı katan abartılı yargılar, anlamsal olarak belirsiz bir çokluğu karşılayarak çokluk kategorisine dâhil edilebilir.

7. En az iki durum arasında yapılan karşılaştırmalar cümleye çokluk anlamı kazandırmaktadır. Bu durum sayılamayan, soyut değerlerin kıyaslandığı hallerde diğerlerinden daha üstün özellik göstererek ölçülemeyen bir çokluğu karşılamamaktadır. 


\section{TARANAN ESER KISALTMALARI}

$\mathrm{O}$

AHDTP

GUY

BVM

$15 \mathrm{~T}$

KA

G

PN

UBG

BDK

TCBEA

ÇDS

OK

KS

ACO

SY

C

$\mathrm{H}$

$\mathrm{R}$

KTS

DG

Gü

KU
: Oyuncak

: Alis Harikalar Diyarında-Tavşanın Peşinden

: Güneşin Uyuduğu Yer

: Bilmeyen Var Mi?

: 15 Temmuz

: Küçük Ağa

: Güvercin

: Püf Noktas1

: Uzayda Bir Gün

: Bir Dâhiyle Konuşmak

: Tamburi Cemil Bey Enstrümanları Anlatıyor

: Çocuk Doğru Söyledi

: Okuma Kitaplarım

: Kitabın Serüveni

: Anadolu'nun Cirit Oyunları

: Sağlıklı Yaşıyorum

: Cazgır

: Hasta

: Reçete

: Kar Tanesinin Serüveni

: Dünyanın Gezginleri

: Gülibik

: Kış Uykusu 


\begin{tabular}{|c|c|}
\hline AG & : Atatürk Gülümsedi \\
\hline BAA & : Ben Atatürk'ün Arkadaşıyım \\
\hline VY & : Vatan Yolunda \\
\hline At & : Ant \\
\hline NNZNME & : Neyi, Ne Zaman, Niçin Merak Ederiz? \\
\hline EKMA & : Eşekli Kütüphaneci Mustafa Amca \\
\hline VCC & : Velcro-Cirt Cirt \\
\hline AÖVK & : Ali’nin Ödevi ve Köstebekler \\
\hline YIDBRE & : Yedi İklim Dört Bucakta Rehberimiz Evliya \\
\hline HGE & : Hey Gidinin Efesi \\
\hline BBKK & : Ben Bir Küçük Kilimim \\
\hline KP & : Küçük Prens \\
\hline ÜKYGD & : Üç Kuşağın Yazarı: Gülten Dayığlu \\
\hline ÖG & : Ödevsiz Gezegen \\
\hline Mİ & : Memleket İsterim \\
\hline AŞG & : Ah Şu Gençler! \\
\hline SKH & : Sağlığına Kavuşan Hasta \\
\hline MS & : Mimar Sinan \\
\hline BBKK & : Ben Bir Küçük Kilimim-7 \\
\hline M & : Mektup \\
\hline AA & : Atatürk’ü Anlamak \\
\hline AKS & : Atatürk Kurtuluş Savaşında \\
\hline Ok & : Okumak \\
\hline KK & : Kitapların Kanatları \\
\hline
\end{tabular}




\begin{tabular}{|c|c|}
\hline DA & : Dört Ahbaplar \\
\hline TK & : Tasa Kuşu \\
\hline SO & : Samimi Olmak \\
\hline $\mathrm{BK}$ & : Balıkçıl Kuşu \\
\hline SK & : Son Kuşlar \\
\hline YOEG & : Yanan Ormanlarda Elli Gün \\
\hline KM & : Kış Mevsimi \\
\hline TDi & : Tatlı Dil \\
\hline KAİVKİ & : Kişiler Arası İletişim ve Kitle İletişimi \\
\hline S & : Selim \\
\hline TNV & : Televizyonda Ne Var? \\
\hline AK & :Atatürk'ün Kişiliği \\
\hline EHÖ & : Eğitimin Hayati Önemi \\
\hline ATDVÖ & : Atatürk'ün Türk Diline Verdiği Önem \\
\hline SGBU & : Sana Gelmez Bu Ufuklar \\
\hline OY & : Otoray Yolculuğu \\
\hline MOBG & : Manisa Ovası'nda Bir Gün \\
\hline Msf & : Misafirliklerimiz \\
\hline KÖ & : Komşuluk Ölüyor \\
\hline BV & : Babamın Vasiyeti \\
\hline Ac & : Acaba \\
\hline OVMS & : Okul ve Meslek Seçimi \\
\hline GBH & : Garip Bir Hediye \\
\hline EÇ & : Eski Çarıklar \\
\hline
\end{tabular}




$\begin{array}{ll}\text { DHK } & \text { : Dokuzuncu Hariciye Koğuşu } \\ \text { SA } & : \text { Selim'i Anarım } \\ \text { Y } & : \text { Yayla } \\ \text { KVDS } & : \text { Karanfiller ve Domates Suyu } \\ \text { DDD } & : \text { Doğayı Derinlemesine Duyumsamak }\end{array}$

\section{KAYNAKÇA}

Ağın Haykır, Hülya; Kaplan, Hüseyin; Kıryar, Ali; Tarakcı, Rasim ve Üstün, Ercan (2017). Ortaokul Türkçe 5 Ders Kitabı. İstanbul, MEB Yayınları.

Aksan, Doğan (2016). Anlambilim, Anlambilim Konuları ve Türkçenin Anlambilimi (1. Bask1). Ankara, Bilgi Yayınevi.

Bozkurt, B. Ümit ve Canlı, Suna (2017). İlköğretim Türkçe 6 Ders Kitabı. Ankara, Başak Yayıncılık.

Bulduk, Türker Barış (2018), "Türkiye Türkçesi Ağızlarında Farklı Bir Öğrenilen Geçmiş Zaman Eki ve Çekimi: -Ip/-Up, IpdUrU/ UpdUrU”, Turkish Studies, 13/20, ss. 225-244.

Bulduk, Türker Barış (2018), "Kelime Başında Y Foneminin Düşmesi: Kabusname ve Türkiye Türkçesi Ağızları Örneği”, Adıyaman Üniversitesi Sosyal Bilimler Enstitüsü Dergisi, Sayı: 30, ss. 944-991.

Erdal, Nihat (2017). İlköğretim Türkçe 8 Ders Kitabı. Ankara, Dörtel Yayınc1lik.

Güner, Galip (2008). "Şekil, İçerik ve Anlam Bağlantısı Bakımından Türkiye Türkçesi Gramerciliği”, Erciyes, 31(362), ss. 15-21.

İlhan, Nadir (2009). Türk Dilinde Çokluk (1. Bask1). Elazı̆̆, Manas Yayıncılık.

Karaağaç, Günay (2013). Dil Bilimi Terimleri Sözlüğü (1. Baskı). Ankara, TDK.

Kerimoğlu, Caner (2008). "Türkiye Türkçesi Gramerciliğinde Çokluk ve İstek Kategorileri”. Modern Türklük Araştırmaları Dergisi, 5(3), ss. 140155.

Türk Dil Kurumu. (2009). Türkçe Sözlük (10. Baskıdan Yapılan Tıpkıbasım). Ankara: TDK Yayınları. 
Vural, Hanifi ve Böler, Tuncay (2012). Ses ve Şekil Bilgisi (2. Baskı). İstanbul, Kesit Yayınları.

Yıldırım, Recep (2017). İlköğretim Türkçe 7 Ders Kitabı. Ankara, Ez-De Yayıncilik. 